\title{
IJCIT
}

(Indonesian Journal on Computer and Information Technology) Journal Homepage: http://ejournal.bsi.ac.id/ejurnal/index.php/ijcit

\section{Penerapan Metode Simple Additive Weighting Dalam Sistem Pendukung Keputusan Pemilihan Smartphones}

\author{
Ferdy Febriyanto ${ }^{1}$, Ibnur Rusi ${ }^{2}$ \\ Sistem Informasi, Universitas Tanjungpura \\ Pontianak, Indonesia \\ e-mail: ferdyf@sisfo.untan.ac.id ${ }^{1}$, ibnurrusi@sisfo.untan.ac.id ${ }^{2}$
}

\begin{abstract}
A B S T R A K
Smartphone merupakan salah satu teknologi yang sangat cepat berkembang, berbagai macam fungsi serta fitur canggih disematkan didalamnya. Para produsen Smartphone juga terus berlomba-lomba untuk memproduksi berbagai macam tipe dan jenis Smartphone setiap tahunnya. Hal ini sering membuat masyarakat kebingungan saat ingin membeli Smartphone dipasaran, karena selain banyaknya ragam Smartphone dari berbagai merk, juga disebabkan ada beberapa jenis Smartphone yang memiliki fitur dan fungsi yang sama hanya berbeda merk. Dengan dibuatnya sistem pendukung keputusan berbasis web ini, para pengguna yang khususnya ingin membeli Smartphone akan mendapatkan rekomendasi berupa perangkingan merk Smartphone berdasarkan kriteria yang diinginkan pengguna. Penerapan metode Simple Additive Weighting (SAW) dalam sistem ini menghasilkan proses perhitungan nilai akhir dengan sangat baik sehingga hasil akhir nilai dapat ditampilkan dari merk Smartphone dengan nilai tertinggi (paling sesuai dengan kriteria pengguna) sampai dengan merk Smartphone dengan nilai terendah (tidak sesuai dengan kriteria pengguna).

Katakunci: peringkat, SAW, smartphone, SPK
\end{abstract}

\begin{abstract}
A B S TR A C TS
Smartphones is one of technology that is very fast developing, various functions and sophisticated features embedded in it. The Smartphone manufacturers also continue to compete to produce various types of Smartphones every year. This makes people confused when they want to buy a Smartphone in the market, because in addition to the many kinds of Smartphones from various brands, also caused by several types of Smartphones that have the same features and functions, only different brands. With this web-based Decision Support System, users who specifically want to buy a Smartphone will get a recommendation a Smartphone brand ranking based on the criteria the user wants. The application of the Simple Additive Weighting (SAW) method in this system results in a very good final value calculation process, so that the final value can be displayed from the Smartphone brand with the highest value (most appropriate based on user criteria) up to the Smartphone brand with the lowest value (not according to user criteria).
\end{abstract}

Keywords: DSS, ranking, SAW, smartphones 


\section{PENDAHULUAN}

Di era milenial sekarang ini dimana mulai banyaknya pemanfaatan teknologi informasi disegala bidang, membuat masyarakat menjadikan gadget sebagai kebutuhan pokok khususnya Smartphone. Dengan semakin beragamnya dan canggihnya teknologi yang disematkan membuat Smartphone digunakan masyarakat untuk membantu berbagai kegiatan mulai dari pekerjaan, hiburan, hingga pendidikan.

Berdasarkan data lembaga riset digital marketing Emarketer memperkirakan pada tahun 2018 jumlah pengguna aktif Smartphone di Indonesia lebih dari 100 juta orang. Sadar akan perkembangan teknologi dan tingginya permintaan pasar Smartphone, membuat produsen Smartphone semakin rutin mengeluarkan produk Smartphone terbaru untuk berbagai sasaran masyarakat setiap tahunnya.

Dikarenakan mulai banyaknya berbagai merk, tipe, dan fungsi dari Smartphone yang sudah beredar dipasaran khususnya Indonesia, membuat masyarakat kebingungan menentukan pilihan saat ingin membeli Smartphone.

Melihat dari permasalahan diatas, maka peneliti mencoba untuk membuat suatu alat bantu pemberian rekomendasi dalam bentuk sistem pendukung keputusan pemilihan Smartphone yang dapat diakses secara online. Pengguna dapat memberikan masukan atau pilihan kriteria apa saja yang diinginkan. Dengan menerapkan Simple Additive Wighting Method (SAW) dalam prosesnya, dari hasil inputan kriteria yang sudah dipilih, pengguna akan mendapatkan hasil berupa perangkingan merk Smartphone mana yang paling sesuai dengan pilihan. Dengan adanya sistem pendukung keputusan ini pengguna mendapatkan informasi yang dapat dijadikan rekomendasi dalam menentukan pilihan saat akan membeli Smartphone.

Dalam pembuatan penelitian ini juga terkait dengan penelitian terdahulu dengan penggunaan metode yang sama, diantaranya yaitu : "Metode Simple Additive Weighting Sebagai Sistem Pendukung Keputusan Penerima Beasiswa Murid Berprestasi" (Hidayat, 2017), dengan penerapan metode Simple Additive Weighting (SAW) pada penelitian tersebut dapat menghasilkan keputusan yang baik dalam penyelesaian dan perhitungan nilai-nilai kriteria yang dimiliki murid, sehingga diketahui hasil yang akurat dalam proses penerima beasiswa murid berprestasi. "Pengembangan Aplikasi Rekomendasi Hotel di Bali dengan Metode Simple Additive Weighting" (Tangganu \& Hansun, 2019) penelitian tersebut dirancang dan dibangun dengan framework Laravel. Aplikasi rekomendasi hotel ini telah diuji oleh user dengan hasil akhir tingkat kepuasan sebesar 71,33\%. Hasil pengukuran usability aplikasi menggunakan USE Questionnaire menunjukkan bahwa aplikasi rekomendasi hotel ini memenuhi keempat aspek yang diperlukan yaitu Usefulness, Satisfaction, Ease of Use, dan Ease of Learn. "Perancangan Sistem Pendukung Keputusan Penilaian Kinerja Dosen Berbasis Web Menggunakan Metode SAW Pada STMIKIM Bandung" (Moch.Ali \& Chandra, 2018) penelitian tersebut dibuat menggunakan metode Simple Additive Weighting (SAW) sebagai metode pengambilan keputusan, dan sistem ini telah terkomputerisasi dan berbasis web serta dapat dijadikan solusi alternatif untuk membantu dalam proses penilaian kinerja dosen sehingga dapat memudahkan STMIK-IM Bandung khususnya pada ketua LPMI dalam pengambilan sebuah keputusan terhadap dosen terkait dengan hasil yang didapat oleh dosen yang bersangkutan sesuai dengan kriteria yang telah ditetapkan. "Sistem Pendukung Keputusan Pemilihan Smartphone dengan Menerapkan Metode Simple Additive Weighting (SAW)" (Harsiti \& Aprianti, 2017) penelitian tersebut diterapkan pada toko WIN Electronic yang mana proses pemberian informasi kepada konsumen untuk memilih Smartphone dilakukan oleh karyawan dengan memperlihatkan aplikasi dan mulai melakukan perhitungan saat konsumen kesulitan dalam memilih Smartphone, sehingga dengan adanya aplikasi ini proses pemilihan Smartphone menjadi lebih efektif dan tidak memakan waktu yang lama.

Sistem pendukung keputusan (SPK) adalah ilmu untuk menyusun pengambilan keputusan yang lebih tepat dari beberapa kriteria yang kebanyakan tidak terpaku pada sebuat syarat dan aturan tetapi lebih dari dua aturan. Salah satu metode dalam sistem penndukung keputusan adalah Metode Simple Additive Weighting (SAW) yang cukup familiar yang mendukung pengambilan keputusan dengan cara membobotkan semua kriteria dann alternatif dan mendapatkan nilai freferensi yang tepat (Limbong, 2013).

SPK merupakan implementasi teori-teori pengambilan keputusan yang telah 
diperkenalkan oleh ilmu-ilmu seperti operation research dan manegement science, hanya bedanya adalah bahwa jika dahulu untuk mencari penyelesaian masalah yang dihadapi harus dilakukan perhitungan iterasi secara manual (biasanya untuk mencari nilai minimum, maksimum, atau optimum), saat ini komputer PC telah menawarkan kemampuannya untuk menyelesaikan persoalan yang sama dalam waktu relatif singkat (Priyanto et al., 2017).

Sistem pendukung keputusan (SPK) biasanya dibangun untuk mendukung solusi atas suatu masalah atau untuk mengevaluasi suatu peluang atau sering juga disebut sebagai aplikasi SPK. Aplikasi SPK biasanya menggunakan CBIS (Computer Based Information System) yang fleksibel, interaktif, dan dapat diadaptasi, yang dikembangkan untuk mendukung solusi atas masalah manajemen spesifik yang tidak terstruktur (Kusrini, 2007).

Multiple Attribute Decision Making (MADM) adalah suatu metode yang digunakan untuk mencari alternatif optimal dari sejumlah alternatif dengan kriteria tertentu. Inti dari MADM adalah menentukan nilai bobot untuk setiap atribut, kemudian dilanjutkan dengan proses perankingan yang akan menyeleksi alternatif yang sudah diberikan (Kusumadewi, 2006).

Pada dasarnya ada 3 pendekatan untuk mencari nilai bobot atribut, yaitu pendekatan subyektif, pendekatan obyektif dan pendekatan integrasi antara subyektif dan obyektif. Masingmasing pendekatan memiliki kelebihan dan kelemahan. Pada pendekatan subyektif, nilai bobot ditentukan berdasarkan subyektifitas dari para pengambil keputusan, sehingga beberapa faktor dalam proses perankingan alternatif bisa ditentukan secara bebas. Sedangkan pada pendekatan obyektif, nilai bobot dihitung secara matematis sehingga mengabaikan subyektifitas dari pengambil keputusan (Kusumadewi, 2006).

Ada beberapa metode yang dapat digunakan untuk menyelesaikan masalah MADM antara lain:
a. Simple Additive Weighting Method (SAW).
b. Weighted Product (WP).
c. ELECTRE.
d. Technique for Order Preference by Similarity to Ideal Solution (TOPSIS).
e. Analytic Hierarchy Process (AHP).
Fuzzy Multiple Attribute Decision Making

(FMADM) adalah suatu metode yang digunakan untuk mencari alternatif optimal dari sejumlah alternatif dengan kriteria tertentu. Inti dari
FMADM adalah menentukan nilai bobot untuk setiap atribut, kemudian dilanjutkan dengan proses perankingan yang akan menyeleksi alternatif yang sudah diberikan. Pada dasarnya, ada 3 pendekatan untuk mencari nilai bobot atribut, yaitu pendekatan subyektif, pendekatan obyektif dan pendekatan integrasi antara subyektif \& obyektif. Masing-masing pendekatan memiliki kelebihan dan kelemahan. Pada pendekatan subyektif, nilai bobot ditentukan berdasarkan subyektifitas dari para pengambil keputusan, sehingga beberapa faktor dalam proses perankingan alternatif bisa ditentukan secara bebas. Sedangkan pada pendekatan obyektif, nilai bobot dihitung secara matematis sehingga mengabaikan subyektifitas dari pengambil keputusan (Kusumadewi, 2006).

Suatu metode pengambilan keputusan untuk menetapkan alternatif terbaik dari sejumlah alternatif berdasarkan beberapa kriteria tertentu. Fitur Umum FMADM:
a. Alternatif
b. Atribut
c. Konflik antar kriteria
d. Bobot keputusan
e. Matriks keputusan

Metode Simple Additive Weighting (SAW) sering dikenal dengan istilah metode penjumlahan terbobot. Konsep dasar metode SAW adalah mencari penjumlahan terbobot dari rating kinerja pada setiap alternatif pada semua atribut. Metode SAW dapat membantu dalam pengambilan keputusan suatu kasus, akan tetapi perhitungan dengan menggunakan metode SAW ini hanya yang menghasilkan nilai terbesar yang akan terpilih sebagai alternatif yang terbaik. Perhitungan akan sesuai dengan metode ini apabila alternatif yang terpilih memenuhi kriteria yang telah ditentukan. Metode SAW ini lebih efisien karena waktu yang dibutuhkan dalam perhitungan lebih singkat (Verina et al., 2012).

\section{METODE PENELITIAN}

Metode pengumpulan data dalam penelitian ini dilakukan dengan cara:

a. Wawancara, pengumpulan data dilakukan peneliti dengan melakukan tanya jawab langsung kebeberapa responden mengenai cara pemilihan kriteria sebelum membeli Smartphone.

b. Pengamatan langsung, pengumpulan data dilakukan peneliti dengan melakukan survei 
secara langsung kebeberapa lokasi jual beli Smartphone.

c. Studi pustaka, pengumpulan data dilakukan peneliti dengan pencarian literatur buku, jurnal, website, serta penelitian terdahulu yang memiliki topik pembahasan terkait.

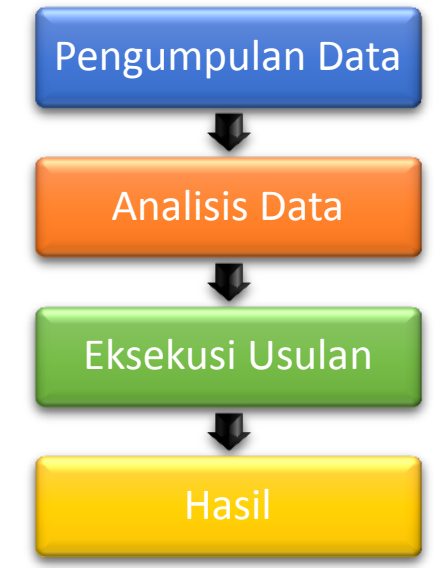

Gambar 1. Tahapan Penelitian

menggunakannya adalah:

Langkah penyelesaian dalam

a. Menentukan alternatif, yaitu $A_{i}$.

b. Menentukan kriteria yang akan dijadikan acuan dalam pengambilan keputusan, yaitu $\mathrm{C}_{\mathrm{j}}$

c. Memberikan nilai rating kecocokan setiap alternatif pada setiap kriteria.

d. Menentukan bobot preferensi atau tingkat kepentingan (W) setiap kriteria.

$W=\left[W_{1}, W_{2}, W_{3}, \ldots, W_{1}\right]$.

e. Membuat tabel rating kecocokan dari setiap alternatif pada setiap kriteria.

f. Membuat matrik keputusan (X) yang dibentuk dari tabel rating kecocokan dari setiap alternatif pada setiap kriteria. Nilai $X$ setiap alternatif $\left(A_{i}\right)$ pada setiap kriteria $\left(C_{j}\right)$ yang sudah ditentukan, dimana, $\mathrm{i}=1,2, \ldots \mathrm{m}$ dan $j=1,2, \ldots n$.

$$
\mathbf{X}=\left|\begin{array}{ccc}
x_{11} & x_{12} \ldots & x_{1 j} \\
\cdot & & \cdot \\
\cdot & & \cdot \\
\cdot & & \cdot \\
x_{i 1} & x_{i 2} & x_{i j}
\end{array}\right|
$$

g. Melakukan normalisasi matrik keputusan dengan cara menghitung nilai rating kinerja ternomalisasi $\left(r_{i j}\right)$ dari alternatif $A_{i}$ pada kriteria $\mathrm{C}_{\mathrm{j}}$.

$$
r_{i j}=\left\{\begin{array}{lr}
\frac{x_{i j}}{\operatorname{Max}_{i} x_{i j}} & \text { jika } j \text { adalah atribut } \\
\text { keuntungan (benefit) } \\
\frac{\operatorname{Min}_{i} x_{i j}}{x_{i j}} \text { jika } j \text { adalah biaya (cost) }
\end{array}\right.
$$

h. Hasil dari nilai rating kinerja ternomalisasi $\left(r_{i j}\right)$ membentuk matrik ternormalisasi $(R)$

$$
R=\left[\begin{array}{ccc}
r_{11} & r_{12} \ldots & r_{1 j} \\
\cdot & & \cdot \\
\cdot & & \cdot \\
\cdot & & \cdot \\
r_{i 1} & r_{i 2} & r_{i j}
\end{array}\right]
$$

i. Hasil akhir nilai preferensi $\left(\mathrm{V}_{\mathrm{i}}\right)$ diperoleh dari penjumlahan dari perkalian elemen baris matrik ternormalisasi (R) dengan bobot preferensi (W) yang bersesuaian eleman kolom matrik (W).

$$
V_{i}=\sum_{j=1}^{n} W_{j} r_{i j}
$$

Nilai $V_{i}$ yang lebih besar mengindikasikan bahwa alternatif $A_{i}$ lebih terpilih.

\section{HASIL DAN PEMBAHASAN}

\subsection{Analisis Data}

Pada tahap ini, peneliti melakukan analisis terhadap data yang sudah didapatkan. Dimulai dari pengelompokkan data, pemberian bobot (w) pada setiap kriteria $(\mathrm{C} 1, \mathrm{C} 2, \ldots)$, memasukkan nilai pada alternatif yang dipilih $(A 1, A 2, \ldots)$, membuat tabel Crips untuk setiap kriteria, proses normalisasi dan melakukan proses rangking dari hasil akhir nilai ternormalisasi.

\subsection{Analisis Simple Additive Weighting}

Tahap awal dalam analisis metode SAW pada penelitian ini adalah membuat kriteria yang akan dipakai dalam sistem.

$$
\begin{aligned}
& \text { C1 }=\text { Layar } \\
& \text { C2 }=\text { Kamera Depan } \\
& \text { C3 }=\text { Kamera Belakang } \\
& \text { C4 }=\text { RAM } \\
& \text { C5 }=\text { Chipset } \\
& \text { C6 }=\text { Storage } \\
& \text { C7 = Baterai }
\end{aligned}
$$

Dari masing-masing kriteria tersebut diberikan bobot nilai yang mana total dari keseluruhan bobot jika dijumlahkan bernilai 100 . 
C1 $(W=25), C 2(W=20), C 3(W=15), C 4(W=$ $15), C 5(W=10), C 6(W=10), C 7(W=5)$.

Mengkategorikan dan memberikan nilai pada masing-masing kriteria (C1, C2, ..., C7). Nilai diberikan berdasarkan tingkat kualitas dari kriteria, yang terbaik diberikan nilai maksimal 100 dan yang terendah diberikan nilai minimum 0 .

Tabel 1. Nilai Kriteria

\begin{tabular}{llll}
\hline Kode & Kriteria & Crips & Nilai \\
\hline C1 & Layar & $6,5^{\prime \prime}-7^{\prime \prime}$ & 100 \\
C1 & Layar & $6,0 "-6,4 "$ & 80 \\
C1 & Layar & $5,5^{\prime \prime}-5,9 "$ & 60 \\
C1 & Layar & $5,0^{\prime \prime}-5,4^{\prime \prime}$ & 40 \\
C1 & Layar & $4,0 "-4,9 "$ & 20 \\
C2 & Kamera Depan & $>30 p x$ & 100 \\
C2 & Kamera Depan & 20px - 29px & 85 \\
C2 & Kamera Depan & $10 p x-19 p x$ & 50 \\
C2 & Kamera Depan & 2px - 9px & 15 \\
C3 & Kamera Belakang & $>30 p x$ & 100 \\
C3 & Kamera Belakang & 20px-29px & 85 \\
C3 & Kamera Belakang & $10 p x-19 p x$ & 50 \\
C3 & Kamera Belakang & 2px - 9px & 15 \\
C4 & RAM & $16 G b$ & 100 \\
C4 & RAM & 8Gb & 80 \\
\hline
\end{tabular}

\begin{tabular}{llll}
\hline C4 & RAM & 6Gb & 65 \\
C4 & RAM & 4Gb & 40 \\
C4 & RAM & 2Gb & 20 \\
C5 & Chipset & Snapdragon 855 & 100 \\
C5 & Chipset & Snapdragon 712 & 90 \\
C5 & Chipset & Snapdragon 710 & 80 \\
C5 & Chipset & Snapdragon 675 & 75 \\
C5 & Chipset & Exynos 9610 & 70 \\
C5 & Chipset & Helio P60 & 50 \\
C5 & Chipset & Helio P22 & 20 \\
C6 & Storage & 128Gb & 100 \\
C6 & Storage & 64Gb & 80 \\
C6 & Storage & 32Gb & 60 \\
C6 & Storage & 16Gb & 20 \\
C7 & Baterai & 4500mAh-5000mAh & 100 \\
C7 & Baterai & 4000mAh-4499mAh & 85 \\
C7 & Baterai & 3000mAh - 3999mAh & 55 \\
C7 & Baterai & 2000mAh - 2999mAh & 15 \\
\hline
\end{tabular}

Tahap selanjutnya adalah membuat tabel alternatif yang dapat dilihat pada tabel 2 dari data produk Smartphone termasuk spesifikasinya sesuai dengan tabel 1 dan diberikan nilai sesuai Crips masing-masing kriteria yang dapat dilihat pada tabel 3.

Tabel 2. Alternatif

\begin{tabular}{|c|c|c|c|c|c|c|c|c|}
\hline $\begin{array}{l}\text { Ko } \\
\text { de }\end{array}$ & Alternatif & $\mathrm{C} 1$ & $\mathrm{C} 2$ & C3 & $\begin{array}{l}\text { C4 } \\
(\mathrm{Gb})\end{array}$ & C5 & $\begin{array}{c}\mathrm{C} 6 \\
\text { (Gb) }\end{array}$ & C7 \\
\hline A1 & Realme 3 Pro & $6,0 "-6,4 "$ & $20 p x-29 p x$ & $20 p x-29 p x$ & 4 & Snapdragon 710 & 64 & 4000mAh- 4499mAh \\
\hline $\mathrm{A} 2$ & $\begin{array}{c}\text { Infinix Hot } 7 \\
\text { Pro }\end{array}$ & $6,0 "-6,4 "$ & $10 p x-19 p x$ & $10 p x-19 p x$ & 6 & Helio P22 & 64 & 4000mAh - 4499mAh \\
\hline A3 & Samsung A50 & $6,0 "-6,4 "$ & $20 p x-29 p x$ & $>30 p x$ & 4 & Exynos 9610 & 64 & 4000mAh - 4499mAh \\
\hline A4 & Realme X & $6,5^{\prime \prime}-7 "$ & $10 p x-19 p x$ & $>30 p x$ & 4 & Snapdragon 710 & 64 & 3000mAh - 3999mAh \\
\hline A5 & $\begin{array}{c}\text { Xiaomi Mi } 9 \\
\text { SE }\end{array}$ & $5,5^{\prime \prime}-5,9^{\prime \prime}$ & $20 p x-29 p x$ & $>30 p x$ & 6 & Snapdragon 712 & 128 & $3000 m A h-3999 m A h$ \\
\hline A6 & $\begin{array}{l}\text { Xiaomi Redmi } \\
\text { K20 Pro }\end{array}$ & $6,0 "-6,4 "$ & $20 p x-29 p x$ & $>30 p x$ & 6 & Snapdragon 855 & 128 & 4000mAh - 4499mAh \\
\hline A7 & Samsung A70 & $6,5 "$ - 7" & $>30 p x$ & $>30 p x$ & 6 & Snapdragon 675 & 128 & 4500mAh - 5000mAh \\
\hline
\end{tabular}

Tabel 3. Nilai Alternatif

\begin{tabular}{lllllllll}
\hline Kode & Alternatif & C1 & C2 & C3 & C4 & C5 & C6 & C7 \\
\hline A1 & Realme 3 Pro & 80 & 85 & 85 & 40 & 80 & 80 & 85 \\
A2 & Infinix Hot 7 Pro & 80 & 50 & 50 & 65 & 20 & 80 & 85 \\
A3 & Samsung A50 & 80 & 85 & 100 & 40 & 70 & 80 & 85 \\
A4 & Realme X & 100 & 50 & 100 & 40 & 80 & 80 & 55 \\
A5 & Xiaomi Mi 9 SE & 60 & 85 & 100 & 65 & 90 & 100 & 55 \\
A6 & Xiaomi Redmi K20 Pro & 80 & 85 & 100 & 65 & 100 & 100 & 85 \\
A7 & Samsung A70 & 100 & 100 & 100 & 65 & 75 & 100 & 100 \\
\hline
\end{tabular}

Setelah masing-masing alternatif (A1, $A 2$, ..., A7) terisi nilai dari kriterianya $(C 1, C 2, \ldots, C 7)$, maka langkah selanjutnya adalah melakukan normalisasi. Proses normalisasi dilakukan sebanyak jumlah kriteria untuk setiap alternatif, yang mana pada kasus diatas terdapat tujuh (7) kriteria C1-C7, sehingga akan dilakukan tujuh (7) kali proses normalisasi.
Untuk menghitung nilai normalisasi, pilih nilai tertinggi pada masing-masing baris (row) kriteria, nilai tertinggi tersebut akan dijadikan nilai pembagi. Misal : Pada baris (row) C1 nilai tertingginya adalah 100, C2 (100), C3 (100), C4 (65), C5 (100), C6 (100), dan C7 (100).

Normalisasi baris (row) $\mathrm{C} 1$ :

$$
\begin{aligned}
& A 1=80 / 100=0,8 \\
& A 2=80 / 100=0,8
\end{aligned}
$$




$$
\begin{aligned}
& A 3=80 / 100=0,8 \\
& A 4=100 / 100=1 \\
& A 5=60 / 100=0,6 \\
& A 6=80 / 100=0,8 \\
& A 7=100 / 100=1
\end{aligned}
$$

Normalisasi baris (row) C2 - baris (row) C6 ... Normalisasi baris (row) C7:

$$
\begin{aligned}
& A 1=85 / 100=0,85 \\
& A 2=85 / 100=0,85 \\
& A 3=85 / 100=0,85 \\
& A 4=55 / 100=0,55 \\
& A 5=55 / 100=0,55 \\
& A 6=85 / 100=0,85 \\
& A 7=100 / 100=1
\end{aligned}
$$

Tabel 4. Normalisasi

\begin{tabular}{llllllll}
\hline Kode & C1 & C2 & C3 & C4 & C5 & C6 & C7 \\
\hline A1 & 0,8 & 0,85 & 0,85 & 0,62 & 0,8 & 0,8 & 0,85 \\
A2 & 0,8 & 0,5 & 0,5 & 1 & 0,2 & 0,8 & 0,85 \\
A3 & 0,8 & 0,85 & 1 & 0,62 & 0,7 & 0,8 & 0,85 \\
A4 & 1 & 0,5 & 1 & 0,62 & 0,8 & 0,8 & 0,55 \\
A5 & 0,6 & 0,85 & 1 & 1 & 0,9 & 1 & 0,55 \\
A6 & 0,8 & 0,85 & 1 & 1 & 1 & 1 & 0,85 \\
A7 & 1 & 1 & 1 & 1 & 0,75 & 1 & 1 \\
\hline
\end{tabular}

Setelah didapatkan nilai normalisasinya, masing-masing nilai ditiap baris (row) kriteria dikalikan $(x)$ dengan masing-masing bobot kriterianya yang sudah ditetapkan diawal.

C1 $(W=25), C 2(W=20), C 3(W=15), C 4$ $(W=15), C 5(W=10), C 6(W=10), C 7(W=5)$.

Misal:

Nilai (row) C1:

$$
\begin{aligned}
& A 1=0,8 \times 25=20 \\
& A 2=0,8 \times 25=20 \\
& A 3=0,8 \times 25=20 \\
& A 4=1 \times 25=25 \\
& A 5=0,6 \times 25=15 \\
& A 6=0,8 \times 25=20 \\
& \text { A7 }=1 \times 25=25
\end{aligned}
$$

Nilai baris (row) C2 - baris (row) C6 ... Nilai baris (row) C7:

$$
\begin{aligned}
& A 1=0,85 \times 5=4,3 \\
& A 2=0,85 \times 5=4,3 \\
& A 3=0,85 \times 5=4,3 \\
& \text { A4 }=0,55 \times 5=2,8 \\
& \text { A5 }=0,55 \times 5=2,8 \\
& \text { A6 }=0,85 \times 5=4,3 \\
& \text { A7 }=1 \times 5=5
\end{aligned}
$$

Tabel 5. Normalisasi

\begin{tabular}{lllllllll}
\hline & \multicolumn{7}{c}{ Bobot } & \\
\cline { 2 - 7 } Kode & 25 & 20 & 15 & 15 & 10 & 10 & 5 & Total \\
\cline { 2 - 7 } & C1 & C2 & C3 & C4 & C5 & C6 & C7 & \\
\hline A1 & 20 & 17 & 12,8 & 9,2 & 8 & 8 & 4,3 & 79,2 \\
A2 & 20 & 10 & 7,5 & 15 & 2 & 8 & 4,3 & 66,8 \\
A3 & 20 & 17 & 15 & 9,2 & 7 & 8 & 4,3 & 80,5 \\
A4 & 25 & 10 & 15 & 9,2 & 8 & 8 & 2,8 & 78 \\
A5 & 15 & 17 & 15 & 15 & 9 & 10 & 2,8 & 83,8 \\
A6 & 20 & 17 & 15 & 15 & 10 & 10 & 4,3 & 91,3 \\
A7 & 25 & 20 & 15 & 15 & 7,5 & 10 & 5,0 & 97,5 \\
\hline
\end{tabular}

Berdasarkan hasil perhitungan nilai pembobotan seperti pada tabel 5 diatas, maka didapatkanlah hasil perangkingan berikut:
a. A7 Samsung A70 $(97,5)$
b. A6 Xiaomi Redmi K20 Pro $(91,3)$
c. A5 Xiaomi Mi 9 SE $(83,8)$
d. A3 Samsung A50 $(80,5)$
e. A1 Realme 3 Pro $(79,2)$
f. A4 Realme $X$ (78)
g. A2 Infinix Hot 7 Pro $(66,8)$

\subsection{Hasil Penerapan}

Agar sistem ini dapat diakses pengguna dimana saja dan kapan saja, maka peneliti mengaplikasikan sistem ini menjadi sebuah web online yang dibuat menggunakan $p h p$ dan MySql.

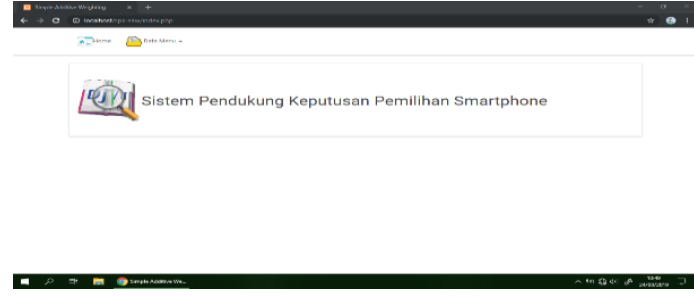

Gambar 2. Home Menu

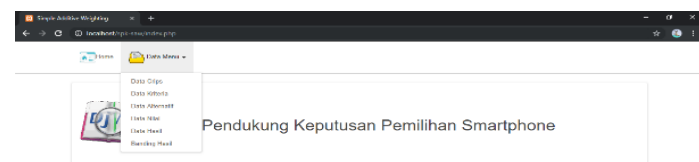

Gambar 3. Data Menu 
Pada menu utama tersebut, pengguna dapat melakukan input maupun memproses data melalui tab data menu (Gambar 3). Dalam data menu terdapat pilihan Data Crips, Data Kriteria, Data Alternatif, Data Nilai, Data Hasil, dan Data Banding Hasil.

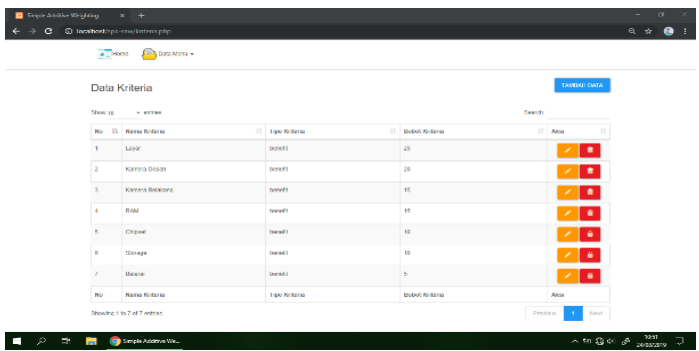

Gambar 4. Data Kriteria

Pada halaman data kriteria pengguna dapat melihat atau menambah data yang akan menjadi kriteria dalam pemilihan Smartphone. Dalam kasus ini peneliti memasukkan kriteria Layar, Kamera Depan, Kamera Belakang, RAM, Chipset, Storage, dan Baterai. Sedangkan nilai bobot diinputkan sesuai kebutuhan pengguna. Kriteria mana yang menjadi pilihan pencarian utama pengguna, maka harus diberikan nilai bobot tertinggi.

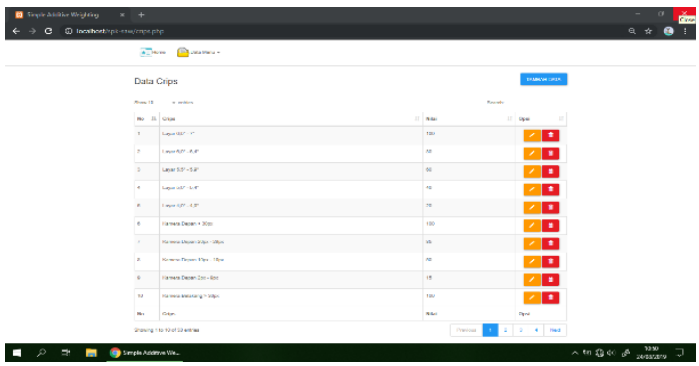

Gambar 5. Data Crips

Pada halaman data Crips pengguna dapat melihat atau menambah data yang menjadi pilihan tipe kriteria Smartphone dengan range nilai $1-100$, semakin baik pilihan tipe kriteria yang diinputkan, maka semakin tinggi pula nilai yang harus dimasukkan.

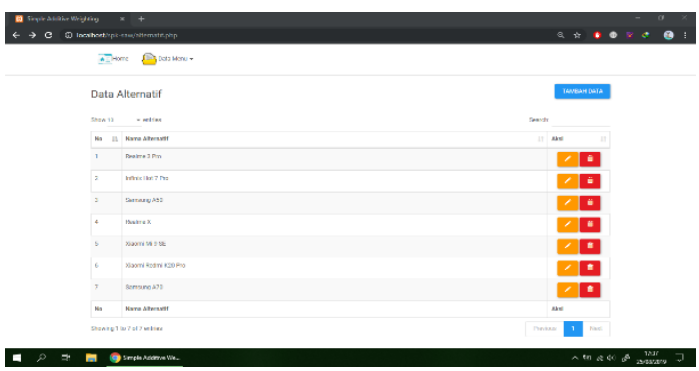

Gambar 6. Data Alternatif
Pada halaman data alternatif pengguna dapat melihat atau menambah data merk atau jenis Smartphone yang akan menjadi pilihan pengguna. Data alternatif ini yang nantinya akan muncul sebagai hasil akhir perangkingan, sehingga dapat dijadikan rekomendasi saat akan membeli Smartphone.

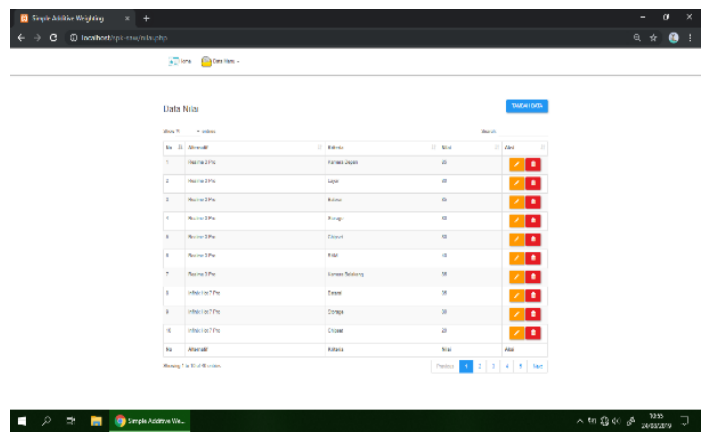

Gambar 7. Data Nilai

Melalui halaman data nilai, pengguna dapat melihat atau menambahkan nilai dan kriteria untuk data alternatif yang sudah diinputkan sebelumnya. Kriteria yang diberikan pada alternatif harus disesuaikan dengan spesifikasi masing-masing merk Smartphone. Sedangkan untuk nilainya diisi dengan range 1 100, jika jenis Smartphone tersebut memiliki kriteria yang bagus, maka nilai yang diberikan harus tinggi.

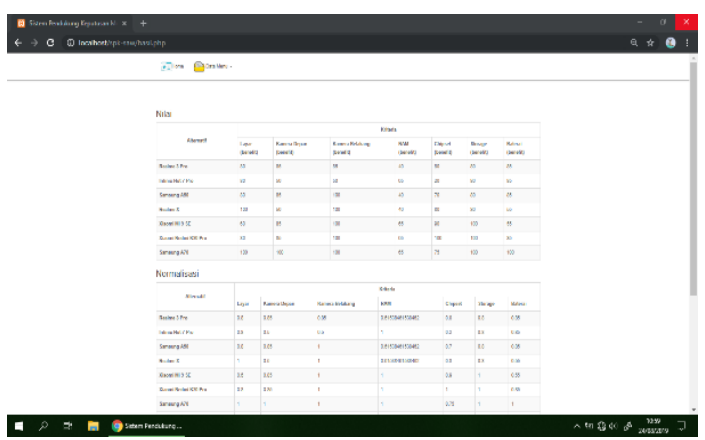

Gambar 8. Data Hasil

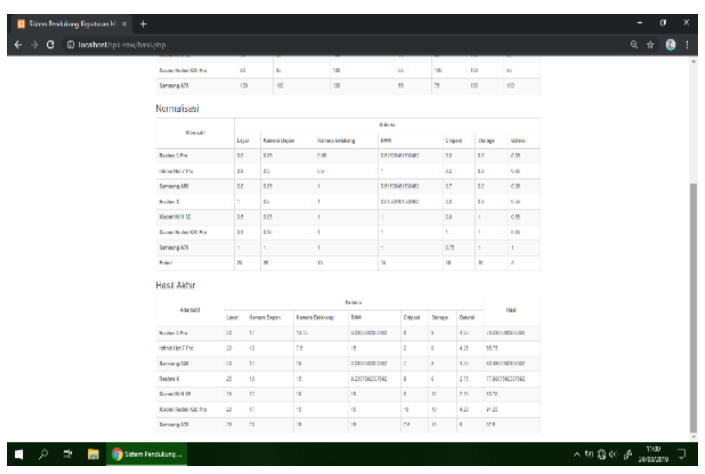

Gambar 9. Data Hasil (Lanjutan) 
Hasil proses perhitungan berdasarkan dari inputan data - data sebelumnya akan ditampilkan pada halaman data hasil dalam bentuk tiga (3) tabel (Gambar 8, dan 9). Tabel pertama menampilkan nilai awal setiap kriteria pada alternatif. Tabel kedua menampilkan hasil nilai yang sudah mengalami proses normalisasi akhir. Dan tabel ketiga menampilkan nilai akhir dari proses pembobotan nilai normalisasi.

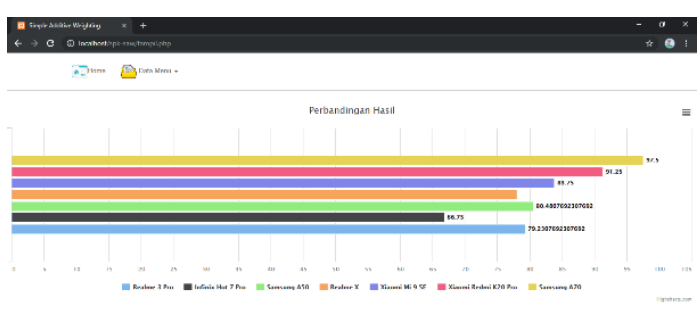

Gambar 10. Grafik Perbandingan Nilai

Perbandingan hasil proses penilaian akan ditampilkan dalam bentuk grafik seperti pada Gambar 10. Merk atau jenis Smartphone yang memiliki nilai tertinggi berarti mempunyai kriteria yang paling sesuai dengan keiinginan dari pengguna. Dengan perbandingan nilai ini, pengguna dapat menjadikan hasilnya sebagai rekomendasi dalam memilih Smartphone yang akan dibeli.

\section{KESIMPULAN}

Berdasarkan hasil penelitian yang telah dilakukan, sistem ini akan sangat membantu dalam memberikan pilihan Smartphone yang sesuai dengan kriteria pengguna, yang mana hasil yang didapat melalui proses perhitungan menggunakan metode SAW sangat baik.

Sistem yang dirancang pada penelitian ini dapat digunakan secara online sehingga sangat membantu pengguna, karena dapat diakses bebas melalui komputer PC, Laptop, Smartphone, maupun tablet yang dapat terhubung internet.

Mengingat sekarang sudah semakin banyak jenis Smartphone dengan berbagai tipe dari banyak produsen, maka diperlukan update data terbaru secara berkala. Hal ini diperlukan untuk dapat menampilkan hasil rekomendasi yang baik dan akurat.

\section{REFERENSI}

Harsiti, H., \& Aprianti, H. (2017). Sistem Pendukung Keputusan Pemilihan Smartphone dengan Menerapkan Metode Simple Additive Weighting (SAW). JSil (Jurnal Sistem Informasi), 4, 19-24.

https://doi.org/10.30656/jsii.v4i0.372

Hidayat, R. (2017). Sistem Pendukung Keputusan Penerima Beasiswa Murid Berprestasi dengan Metode Simple Additive Weighting. Jurnal Sisfotek Global, 2(2), 13-17.

Kusrini. (2007). Konsep dan Aplikasi Sistem Pendukung Keputusan. In Andi, Yogyakarta.

Kusumadewi, S. H. (2006). Fuzzy Multi-Attribute Decision Making (Fuzzy MADM). Graha Ilmu Yogyakarta.

Limbong, T. (2013). IMPLEMENTASI METODE SIMPLE ADDITIVE WEIGHTING (SAW) UNTUK PEMILIHAN PEKERJAAN BIDANG INFORMATIKA. Proceeding SNIKOM.

Moch.Ali, R., \& Chandra, A. (2018). Perancangan Sistem Pendukung Keputusan Penilaian Kinerja Dosen Berbasis Web Menggunakan Metode Saw Pada StmikIm Bandung. Jurnal Informasi, X(2), 4477.

Priyanto, F. S., Harijanto, B., \& Watequlis, Y. (2017). SISTEM PENDUKUNG KEPUTUSAN PEMILIHAN GURU BERPRESTASI MENGGUNAKAN METODE PROMETHEE (Studi Kasus: Dinas Pendidikan Kota Malang). Jurnal Informatika Polinema. https://doi.org/10.33795/jip.v3i4.39

Tangganu, E., \& Hansun, S. (2019). Pengembangan Aplikasi Rekomendasi Hotel di Bali Dengan Metode Simple Additive Weighting. Fountain of Informatics Journal, 4(1), 24-31. https://doi.org/10.21111/fij.v4i1.3080

Verina, V., Yohana, D. L., \& Kartina, D. K. W. (2012). Aplikasi Tutorial Sistem Pendukung Keputusan Menggunakan Metode Simple Additive Weighting. Jurnal Aksara Komputer Terapan Politeknik Caltex Riau, 1(2), 1-8. 